\title{
Del botijo a la lechuza. La cerámica qom en el último siglo
}

\section{Resumen}

En este artículo presentamos una descripción de los atributos más significativos en la cerámica realizada por el pueblo Qom a lo largo del último siglo. La disponibilidad de materiales de distintas cronologías en las instituciones museísticas, junto con la memoria oral de alfareros en activo en varias localidades de la provincia de Chaco, permite trazar un recorrido diacrónico de la fabricación y uso de esta tecnología. Su vinculación con los distintos ámbitos en los que se desarrolló la vida de este pueblo da cuenta de la participación activa de este elemento material en términos funcionales, pero también simbólicos. En diversos momentos entra en juego una serie de valores que se actualizan o se rechazan según la intencionalidad de la sociedad de la que forman parte y se reflejan en la técnica de manufactura, la composición, el tratamiento de superficie, la morfología y la decoración. Asimismo, el conjunto generado evidencia los contactos que los Qom fueron estableciendo con otros pueblos desde la vida en el monte de principios del siglo XX a la ocupación de tierras restituidas y cordones urbanos en la actualidad.

\section{From the pitcher to the owl. Qom pottery in the last century}

\begin{abstract}
This article describes the most relevant attributes of qom pottery throughout the last century. The availability of vessels of different chronologies in museum collections, together with the oral memory of Chaco potters, is used to make a diachronic definition of the making and use of this technology. Furthermore, its association with different living contexts accounts for the active participation of ceramics in both functional and symbolic terms. On several occasions, a series of values are either actualized or rejected, depending on the intentions of the producing society. These values are reflected in the manufacturing technique, composition, surface treatment, morphology, and decoration. Moreover, the resulting assemblage evidences the contacts established by the Qom with other people from their life in the forest, at the beginning of the 20th century, to their settlement in recovered lands and in the urban periphery nowadays.
\end{abstract}

\section{Palabras clave}

Revitalización artesanal Identidad

Funcionalidad doméstica Elecciones tecnológicas y decorativas

Colecciones museísticas

\section{Keywords}

Crafts revitalization Identity Domestic functionality Technological and decorative choices

Museum collections 


\section{Introducción}

En el imaginario popular sobre los pueblos chaqueños, la cerámica qom destaca como la mejor conocida. Sin embargo, esta idea se origina en gran parte por la difusión fuera del Gran Chaco de ciertas producciones enfocadas a un público general y con una fuerte orientación comercial. Pese a no conformar el núcleo de lo que podríamos pensar como cerámica tradicional, estos diseños, como veremos luego, no dejan de ser representativos de la idiosincrasia qom, y se erigen como reivindicaciones de su cultura. Luego de una primera incursión en el circuito comercial nacional hacia las décadas de 1960-1970, en el siglo XXI la presencia de la cerámica qom se reactiva a través de los procesos de visibilización y reivindicación llevados a cabo por este pueblo, que incluyen la exhibición y venta de productos elaborados en los asentamientos urbanos (o barrios tobas).

La cerámica qom tiene, empero, una historia mucho más larga y —a diferencia de otros grupos chaqueños, como los Wichí o los Chorote (Vidal, 2018b) - sumamente cambiante según las condiciones sociales, económicas y culturales a las que se ha tenido que acomodar este pueblo otrora montaraz. No contamos hasta el momento con un desarrollo diacrónico de esta tecnología que nos permita evaluar los cambios y las pervivencias, así como el papel que jugó en la organización socio-económica de los Qom. Ello repercute negativamente en una política de gestión cultural y salvaguarda de los bienes, al no disponer de un contexto amplio en el cual ubicar las piezas cerámicas conservadas en museos e instituciones de investigación. A su vez, resta importancia al valor patrimonial material e inmaterial de una expresión viva que recoge de períodos anteriores técnicas, modelos y simbolismo, y los reinterpreta de acuerdo con las condiciones de vida e intereses de sus creadores. Por último, creemos que es importante analizar el desarrollo de esta expresión cultural unificando esfuerzos con las comunidades indígenas que consideran -al igual que gran parte de la comunidad académica- que el mayor conocimiento de la historia cultural propia es un pilar para la reivindicación de la identidad y las buenas relaciones entre culturas. En este sentido, proponemos una descripción diacrónica de las características que presenta la cerámica qom desde comienzos del siglo XX a la actualidad, a través de las colecciones de museo y los relatos de alfareros documentados hasta el momento. Debido a la dispersión de los materiales qom disponibles en las colecciones etnohistóricas y contemporáneas, se han relevado los materiales existentes en museos de la Ciudad Autónoma de Buenos Aires (CABA, Argentina), de la provincia de Chaco (Argentina) y de Madrid (España). La posibilidad de contar con alfareros en activo de esta etnia y su interés en dar a conocer sus trabajos permitió asimismo plantear algunas cuestiones invisibles en el soporte material.

\section{La muestra de estudio}

Pese a que distintas instituciones museísticas cuentan con cerámica chaqueña, es muy frecuente que las muestras tengan un importante sesgo temporal y étnico, debido fundamentalmente a las condiciones en las que se formaron las distintas colecciones. Por ello se hace necesario apelar a una variedad de museos y complementar esta información con los relatos y la observación de las prácticas de los alfareros qom que en la actualidad habitan en la zona chaqueña y en aquellas localidades a las que se desplazaron a finales del siglo pasado.

\section{Museos consultados}

Hasta el momento hemos podido relevar los materiales cerámicos de los pueblos originarios chaqueños del Museo Nacional del Hombre (Instituto Nacional de Antropología y Pensamiento Latinoamericano, CABA), del Museo Histórico Regional "Ichoalay" y del Museo del Hombre Chaqueño "Ertivio Acosta" (Resistencia, Chaco), 
del Museo de América (Madrid) y del Museo de Charata (Chaco), así como una muestra limitada del Museo Etnográfico "Juan Bautista Ambrosetti” (Universidad de Buenos Aires; CABA) y del Museo de Artesanías Indígenas "René James Sotelo" (Quitilipi, Chaco). Quedan pendientes las colecciones del Museo de La Plata y las de la Universidad Nacional de Tucumán, cuyos materiales se superponen cultural y cronológicamente con los estudiados en otras instituciones. Además, se incluyen observaciones a partir de las piezas cerámicas que tenían disponibles los alfareros actuales en sus viviendas.

La disponibilidad de materiales cerámicos identificados como qom en los museos consultados es bastante limitada y está posiblemente marcada por los intereses de la época de la recolección. Como se puede ver en la Tabla 1, combinando los datos de los siete museos estudiados fue posible recorrer la trayectoria de la cerámica qom desde principios del siglo XX hasta la época actual, minimizando las lagunas por falta de materiales aunque, como veremos, hay períodos en los que la visibilización de la alfarería estuvo prácticamente ausente.

Esta separación cronológica se debe en gran medida a la historia individual de cada museo y sus colecciones. Según consta en los registros, el acervo pertinente del Museo Etnográfico corresponde a los materiales recolectados por Enrique Palavecino en 1935, transferidos desde el Museo de Ciencias Naturales "Bernardino Rivadavia” (Pegoraro y Elías, 2010), una pieza de la expedición O’Donell al Chaco de 1909 y la compra de cerámica qom a Lynch Arribalzaga, también a principios de siglo. Dominan en el inventario los botijos (ver infra), aunque también se localizaron jarras y platos sin decoración alguna, que indican un rango más amplio de selección. Su comparación con el ingreso de materiales wichí similares ofrece una idea más clara de su representatividad, ya que no se limitan a una sola forma.

La colección de cerámica qom del Museo "Ichoalay" fue recolectada por el Seminario homónimo dentro de las actividades de la Escuela Normal "Sarmiento" de Resistencia. Según relataron ex-alumnas que residen en dicha ciudad, esta actividad incluía salidas de campo a los parajes chaqueños entre las décadas de 1940 y 1950 (Romero, 2017), para conocer a los pobladores y adquirir artesanías que fueron donadas al museo fundado por Inés García de Marqués. Las piezas estaban en uso en el momento de su recogida, indicando su contemporaneidad y vigencia.

Los materiales del Museo de América de Madrid también están vinculados a la fundadora del Museo Ichoalay. Ingresaron en la institución en 1970 con motivo de una muestra sobre cultura argentina (Vidal, en prensa) y fueron recogidas por voluntarias de la Cruz Roja. Una de las personas que participó en el envío relata que los materiales enviados eran piezas de artesanos individuales que vivían en el Barrio Toba de Resistencia en la segunda mitad de la década de 1960 (B. Castaño, comunicación personal, 2019). Asimismo, la alfarera qom Jessica Chara identificó la factura de su tío abuelo - en activo en esa misma época- en algunos modelos.

Pese a que el Instituto Nacional de Antropología (ahora INAPL) participó en el proyecto financiado por el Consejo Federal de Inversiones para la producción y difusión de artesanías chaqueñas de finales de la década de 1960 (ver infra), el Museo Nacional del Hombre recibió una muestra muy reducida de cerámicas qom, que corresponde a las miniaturas elaboradas en esas época como recuerdo de viaje. Ello contrasta llamativamente con la importante colección de otros pueblos chaqueños, como los Wichí o Moqoit, o incluso los Avá-chané.

La colección del Museo del Hombre Chaqueño es más dispar. Se compone principalmente de donaciones e incluye piezas de las décadas de 1960 y 1970 (algunas 


\begin{tabular}{|c|c|c|c|}
\hline Museo & Cantidad de ejemplares & Cronología & Forma de ingreso \\
\hline $\begin{array}{c}\text { Museo Etnográfico “Juan Bautista } \\
\text { Ambrosetti” (CABA) }\end{array}$ & 7 (analizadas) & $\begin{array}{c}1909-1950 \\
\text { (mayoritariamente 1935) }\end{array}$ & $\begin{array}{l}\text { Recogida en terreno y donación } \\
\text { de investigadores }\end{array}$ \\
\hline $\begin{array}{l}\text { Museo Histórico “Ichoalay” } \\
\text { (Resistencia, Chaco) }\end{array}$ & 16 & $1940-1950$ & $\begin{array}{l}\text { Recogida en terreno y donación } \\
\text { del "Seminario Ichoalay" }\end{array}$ \\
\hline $\begin{array}{l}\text { M. Nacional del Hombre-INAPL } \\
\text { (CABA) }\end{array}$ & 7 & $1960-1970$ & $\begin{array}{l}\text { Recogida en terreno y donación } \\
\text { de investigadores }\end{array}$ \\
\hline Museo de América (Madrid) & 58 & $\begin{array}{c}1970 \text { (elaboradas entre } \\
1965-1969)\end{array}$ & $\begin{array}{c}\text { Donación de miembros de la Cruz } \\
\text { Roja en Resistencia }\end{array}$ \\
\hline $\begin{array}{l}\text { Museo del Hombre Chaqueño } \\
\text { “Ertivio Acosta” (Resistencia, Chaco) }\end{array}$ & 4 & $\begin{array}{l}1960-1970 \\
2000\end{array}$ & Donaciones varias \\
\hline Museo de Charata (Chaco) & 3 & $1990-2000$ & $\begin{array}{l}\text { Donación y compra a alfareros } \\
\text { locales }\end{array}$ \\
\hline $\begin{array}{l}\text { Museo de Artesanías Indígenas } \\
\text { "René James Sotelo" (Quitilipi, } \\
\text { Chaco) }\end{array}$ & 31 (analizadas) & $1969-2018$ & $\begin{array}{l}\text { Recogida en terreno por el } \\
\text { fundador y compra y donación de } \\
\text { obras de las ferias de artesanía }\end{array}$ \\
\hline
\end{tabular}

Tabla 1. Colecciones museográficas relevadas. Se presentan la cantidad de ejemplares disponibles y/o analizados junto con su cronología y la forma de ingreso a la institución.

de los mismos alfareros de la colección del Museo de América) y otras de comienzos de este siglo, además de juegos y juguetes de arcilla. Algo similar ocurre con el Museo de Charata, que solo posee tres ejemplares de cerámicas correspondientes a finales del siglo XX y principios del XXI, ingresados por compra y donación. Por el contrario, el museo exhibe una nutrida colección de cerámicas de cronologías más antiguas, aunque no es posible precisar el grupo que las elaboró debido a la escasez de datos contextuales y analíticos (O. González, comunicación personal, 2018).

Finalmente, el Museo de Artesanías Indígenas conserva los materiales recolectados por René Sotelo en distintos parajes y muestras de los trabajos expuestos en las Ferias de Artesanías Indígenas desde su inicio en 1969 hasta la actualidad. A falta de registros precisos, y considerando que muchas de las piezas son miniaturas, se calcula que el volumen de piezas supera los 400 ejemplares (N. Aguirre, comunicación personal, 2019).

En todos los casos, para el registro morfo-tecnológico se tuvieron en cuenta los siguientes parámetros: forma y tamaño, composición, técnica de manufactura, acabado de superficie, decoración y apéndices. Por cuestiones organizativas, en dos de las instituciones (Museos Ambrosetti y Sotelo) el registro del grueso de las piezas se limitó a una observación visual de los rasgos sobresalientes y se analizó una muestra reducida. En el resto, se reconocieron estos atributos en la totalidad de las piezas.

\section{Entrevistas a alfareros/as qom actuales}

Durante la primavera de 2017 y el verano de 2018 realizamos entrevistas y observación del trabajo de alfareros y alfareras qom en distintas localidades de la provincia de Chaco. La información presentada para los momentos actuales (y en algunos casos, anteriores) fue generosamente facilitada por los artesanos Jessica Chara (JC) y Teresa Pichón (TP) de Resistencia, Vicente Segundo (VS) de Fontana, Sara Ortega (SO) y Patricia Gómez (PG) de Quitilipi-Colonia Aborigen y Ema Méndez (EM) de Miraflores. Hemos incluido además la documentación recogida por el Instituto de Patrimonio Cultural Inmaterial de la provincia de Chaco para complementar los datos del alfarero qom Vicente Segundo.

Las entrevistas fueron estructuradas en cuanto a temáticas pero suficientemente amplias para permitir que los alfareros pudieran incorporar aquellas cuestiones que les parecían importantes. Los temas consultados abarcaron la elección de la profesión, el contexto 
familiar, el proceso de aprendizaje, el lugar y tiempo de trabajo, la técnica utilizada y las etapas seguidas, la posibilidad de introducir modificaciones, el significado de las piezas, sus destinatarios, la experiencia de venta y participación en ferias/eventos y su proyección de futuro. Además, se les consultó sobre las características de las cerámicas de los museos estudiados a partir de su registro fotográfico. Todos los alfareros aportaron materiales de muestra y datos de gran interés para reconstruir el proceso técnico de modelado de las piezas. Algunos incluso ofrecieron fotografías y realizaron piezas para documentar dicho proceso.

\section{Un siglo de historia en la cerámica qom}

\section{El material arqueológico}

El registro arqueológico de la cerámica chaqueña se remonta a una cronología de principios de la era cristiana (Calandra et al., 2004; Lamenza, 2015; Lamenza, Aguirre y Calandra, 2005). Sin embargo, pese a que es muy frecuente que aparezcan fragmentos de cerámica en distintas zonas de la provincia, la información sobre hallazgos contextualizados es escasa. El Museo de Charata, por ejemplo, expone una interesante colección de piezas halladas en distintos sitios que comparten ciertas características tecnológicas con las producciones posteriores (uso de desgrasante de hueso calcinado, modelado por rollos superpuestos con encabalgamiento externo, bases redondeadas, superficies alisadas), pero se distinguen de estas últimas por una variada decoración que incluye pintura roja, incisiones e impresiones de cordel, tejidos, moluscos y digitounguiculados. A estas cerámicas se le asignó una antigüedad precolonial, pero en la mayoría de los casos se carece de fechados directos (Lamenza, 2015). Pese a los rasgos tecnológicos compartidos - que, por otro lado, también son comunes a la alfarería wichí, chorote, o moqoit antigua (Vidal, 2018b) —, creemos que no puede establecerse, con la evidencia actual, una continuidad con la cerámica qom del último siglo, y sería demasiado arriesgado tomarla como antecedente.

\section{La cerámica qom a comienzos del siglo $X X$}

Debido a que en este artículo proponemos limitarnos a la consideración de aquellos momentos en que tenemos registro efectivo de la elaboración de cerámica qom (ya sea documentación material, bibliográfica o relatos de alfareros actuales), comenzamos la presentación con la situación a comienzos del siglo XX. No queremos decir con ello que sea el comienzo de la producción alfarera de este pueblo - lo cual nos parece sumamente inverosímil debido a la buena calidad de los recipientes disponibles-, pero no nos es posible adentrarnos en épocas anteriores por el momento. Tampoco es nuestra intención explayarnos en el estilo de vida de movilidad territorial de los Qom previo a la conquista militar y la expansión de la frontera agrícola y de explotación por parte de colonos inmigrantes, ya que se encuentra relatado en distintos documentos, tanto los recopilados por los propios Qom (Chico, 2017; Sánchez, 2007) como por los investigadores de principios del siglo pasado (por ejemplo, Métraux, 1946; Nordenskiöld, 1920; Palavecino, 1944; Vellard, 1933) y actuales (Arenas, 2003; Braunstein, 1983; Cordeu y Siffredi, 1971; Giordano, 2012; Tola, 2012; Trinchero, 2000; Wright, 1998, 2005, entre muchos otros). Bastará con recordar que tenían una estrategia de subsistencia cazadora, pescadora, melera y recolectora (la marisca), con movilidad estacional y una organización social basada en bandas nómades exógamas, generalmente bilaterales y uxorilocales (Braunstein, 1983) compuestas por pocos miembros vinculados por lazos familiares que se reforzaban en la frecuente reocupación de sitios (Sánchez, 2007).

Corresponde también a esta época la denominada "campaña al desierto verde" que dio origen al genocidio de los indígenas del Chaco (Chico, 2017) y que de una forma u otra se 
perpetúa hasta la actualidad con las políticas de expropiación de tierra, marginalización, escasez de recursos alimentarios, hídricos y sanitarios, así como de discriminación étnica y cultural (Wright, 2001). Los desplazamientos a corta distancia de los pueblos afectados y su reubicación en zonas marginales también conforman el contexto en que se utilizó esta primera manifestación cerámica qom identificada hasta el momento.

Las piezas más antiguas conservadas en los museos consultados (1909 y 1913-14) responden a tres botijos y una jarra. Contemporáneamente se redacta el primer documento que hemos hallado donde se menciona a un hombre qom trabajando una vasija cerca de la misión de Laishí, Formosa (Nícklison, 1916). Allí se describe su realización mediante la superposición de rollos dentro de un pozo que actuaría a manera de molde. Si bien no podemos descartar el uso de esta técnica, ninguna de las piezas revisadas presenta encabalgamiento interno en la parte inferior, un rasgo esperable en el caso de que el modelado se realizara con un molde externo. Por el contrario, la técnica de las piezas analizadas responde más cabalmente al trabajo sin molde.

En términos generales, los recipientes qom disponibles en los museos para los momentos en que predominaba la vida móvil en el monte están vinculados a la gestión del agua y tienen un aire familiar con la cerámica producida por el resto de los pueblos chaqueños (Palavecino, 1944; Susnik, 1998). La información que hemos recogido entre los alfareros qom (SO y VS) confirma las menciones de autores clásicos como Palavecino, Métraux y Nordenskiöld sobre este uso específico de las vasijas. Asimismo, esta información se condice con el estudio ceramológico que hemos realizado de los botijos de la época, que destaca su posible utilización para el trasporte de líquidos en términos funcionales y morfológicos (Vidal, 2018a).

El denominado "botijo toba" o qom (Cerrutti, 1966, pp. 57-58; Palavecino, 1944) se refiere a una pieza cuya altura y diámetro máximo (excluyendo los apéndices) tienen dimensiones similares. En el caso de esta etnia, existen ejemplares de formas aproximadamente esféricas, compuestos ya sea por dos hemiesferas o por una mitad hemiesférica y otra troncocónica superpuestas (Figura 1). En algunos casos, ambas partes se unen describiendo una carena en el punto de inflexión o minimizando el mismo en una forma más globular. Otra alternativa es el botijo formado por dos hemiesferas unidas con una depresión central que facilita la sujeción posterior de una cuerda para su transporte, una costumbre que aún recuerdan los informantes de más edad.

Algunas de las piezas presentan una base aplanada, sobre todo las realizadas con posterioridad al contacto con los misioneros y los colonos de origen europeo de principios del siglo XX, pero las más antiguas suelen tener una base de tendencia cónica o esférica. En todos los casos las piezas describen un punto de inflexión central y un hombro, seguido por un cuello troncocónico o tubular y labio engrosado o superpuesto. Representan recipientes de buen tamaño, con una capacidad media estimada en base a su descomposición geométrica (Rice, 1986) en unos 5,5 litros. Pese a ello, son recipientes relativamente livianos, de paredes finas (menores de $9 \mathrm{~mm}$ ), muy apropiados para ser movilizados.

Si bien los relatos y la función asignada a esta pieza indican que fue un elemento frecuente dentro del repertorio cerámico qom tradicional, creemos que se encuentra sobrerrepresentada en las colecciones museísticas, debido quizás a su peculiar morfología. Sin embargo, la disponibilidad de un conjunto completo de cerámicas wichí que incluye botijos similares (Museo Sotelo) indica que estos recipientes no tendrían un valor individual sino que participarían dentro de un complejo que podríamos denominar "de tratamiento de agua" (Vidal, 2018a), del cual presenta una síntesis uno de los alfareros qom consultados (VS): 

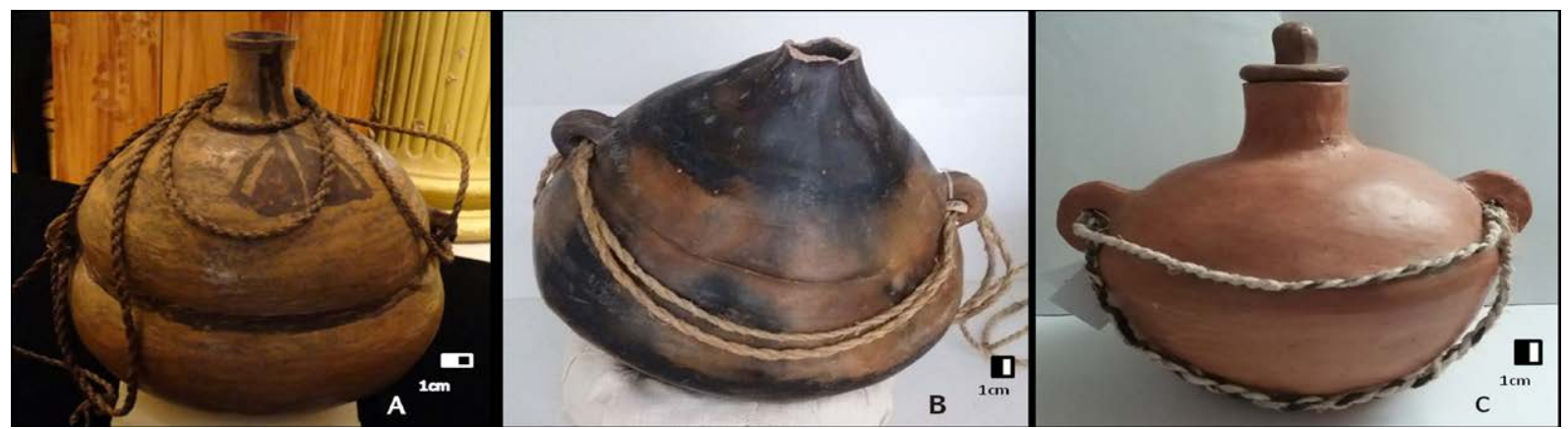

Figura 1. Botijos qom: A) con depresión central (Museo Etnográfico “J. B. Ambrosetti”); B) mitad troncocónica superpuesta a hemiesférica con depresión central (Museo Histórico Regional "Ichoalay"); C) mitades cónicas superpuestas sin depresión, réplica actual realizada por el maestro Vicencio Segundo según el modelo que recuerda de su abuela (colección particular) (fotografías de la autora).

El agua se extraía de ríos o lagunas y para purificar el agua turbia se echaban cenizas blancas dentro del recipiente. Luego de una o dos horas más o menos, quedaba toda la suciedad en el fondo. Entonces se pasaba el agua limpia en otra vasija (Segundo, 2016, p. 2).

A esta segunda vasija se le sumaría una tercera que consistiría en un cuenco para la extracción y el consumo in situ, o incluso recipientes más pequeños para su transporte, ya sean de cerámica, de madera de yuchán (Ceiba chodatii, Bombacaceae), de distintos tipos de calabaza (Susnik, 1998) o incluso de bolsas de materias animales (Alvarsson, 2012). Otras culturas chaqueñas elaboraron las denominadas "cantimploras" o "caramañolas", recipientes globulares pequeños para el transporte de agua (Vidal, 2018b). Como recalca el alfarero, el proceso de depuración y decantación mediante el trasvase del líquido a múltiples recipientes era facilitado por la acción de las cenizas de hueso molido. A su vez, este material fue el principal desgrasante de los botijos tradicionales, coadyuvando al proceso de depuración. Cabe señalar que en Chaco es frecuente denominar "hueso" tanto al material óseo como a la conchilla de agua dulce, si bien algunos alfareros, como los moqoit, sostienen que sus propiedades son diferentes y se deben seleccionar según el tamaño y la funcionalidad de la pieza (Vidal, en prensa).

Los botijos se realizaron mediante la superposición de rollos en espiral continua, con encabalgamiento externo en la mitad inferior para facilitar la ampliación del diámetro y encabalgamiento interno en la superior, para reducirlo (Tabla 2). A ambos lados de la zona central -ya sea deprimida o carenada- se colocaron pequeñas asas de mamelón perforadas para sostener algún elemento de suspensión orgánico, generalmente fibra de cháguar (Bromelia hieronimi) (SO y VS), como se aprecia en algunas piezas. El acabado de superficie consiste en un alisado cuidadoso o incluso un pulido muy somero, en ocasiones decorado con figuras geométricas (rombos, dos cuartos de círculo enfrentados, líneas pareadas en zig-zag) que en la mayoría de los casos solo están dibujados y solo en el diseño de los cuartos de círculo se ha rellenado su interior (Figura 1). Estas decoraciones se localizan en la parte superior del cuerpo y posiblemente se realizaron con resina de palo santo (Bursera graveolens), que otorga el característico aspecto de brea observado en los recipientes decorados.

Si bien es imposible asegurar que contamos con el repertorio completo, los relatos de los alfareros qom actuales coinciden en que la cerámica se utilizaba para la conservación de líquidos y alimentos, y solo algunas comidas, como las sopas de pescado, se hervían (Arenas, 2003). La única posible olla disponible se encuentra en el Museo "Ichoalay" y corresponde a un recipiente de unos 4,5 litros que no posee rastros de haber sido expuesta al fuego. En este museo también se conserva un conjunto de materiales de manufactura somera que incluyen una jarra, una tinaja, un plato y un cuenco decorado 


\begin{tabular}{|c|c|c|c|c|c|}
\hline Tipo & Desgrasante & Técnica & Acabado superficial & Decoración & Cocción \\
\hline $\begin{array}{c}\text { Botijo } \\
\text { (comienzos s. XX) }\end{array}$ & $\begin{array}{l}\text { Hueso calcinado } \\
\text { molido }\end{array}$ & $\begin{array}{c}\text { Rollos } \\
\text { (e. interno/externo) }\end{array}$ & Alisado & (Pintura) & Oxidante \\
\hline $\begin{array}{l}\text { Jarra /olla/cántaro } \\
\text { (comienzos s. XX) }\end{array}$ & $\begin{array}{l}\text { Hueso calcinado } \\
\text { molido }\end{array}$ & $\begin{array}{c}\text { Rollo } \\
\text { (e. interno/externo) }\end{array}$ & Alisado & - & $\begin{array}{l}\text { Reductora / } \\
\text { oxidante }\end{array}$ \\
\hline $\begin{array}{c}\text { Plato/cuenco } \\
\text { (comienzos s. XX) }\end{array}$ & $\begin{array}{l}\text { Hueso calcinado } \\
\text { molido }\end{array}$ & $\begin{array}{c}\text { Rollos } \\
\text { (e. externo) }\end{array}$ & Alisado & - & Reductora \\
\hline \multirow{2}{*}{$\begin{array}{l}\text { Vasijas decorativas } \\
\quad(1960-1970)\end{array}$} & $\begin{array}{l}\text { Hueso calcinado } \\
\text { molido }\end{array}$ & \multirow{2}{*}{$\begin{array}{c}\text { Rollos } \\
\text { (e. interno/externo) }\end{array}$} & \multirow{2}{*}{ Pulido } & $\begin{array}{l}\text { (Modelado de } \\
\text { rostro) }\end{array}$ & $\begin{array}{l}\text { Oxidante / } \\
\text { Reductora }\end{array}$ \\
\hline & Aserrín & & & - & Oxidante \\
\hline $\begin{array}{l}\text { Estatuillas } \\
\text { (196o-hoy) }\end{array}$ & Aserrín & Modelado & $\begin{array}{c}\text { Pulido } \\
\text { (con betún) }\end{array}$ & Pintura & Oxidante \\
\hline $\begin{array}{l}\text { Miniaturas } \\
\text { (196o-hoy) }\end{array}$ & Aserrín & $\begin{array}{l}\text { Ahuecado/rollos } \\
\text { (e. interno) }\end{array}$ & Alisado / pulido & (Pintura) & Oxidante / sin cocer \\
\hline $\begin{array}{l}\text { Animales } \\
\text { (196o-hoy) }\end{array}$ & Aserrín & Ahuecado & Alisado / barniz & Pintura & Oxidante \\
\hline $\begin{array}{l}\text { Vasijas decorativas } \\
\text { (comienzos s. XXI) }\end{array}$ & Aserrín & $\begin{array}{c}\text { Rollos } \\
\text { (e. interno/externo) }\end{array}$ & Alisado / pulido & $\begin{array}{l}\text { (Pintura/ } \\
\text { modelado) }\end{array}$ & Oxidante \\
\hline
\end{tabular}

Tabla 2. Características más relevantes de los distintos tipos (antiguos y actuales) relevados en la cerámica qom. Entre paréntesis, las menos frecuentes.

con una línea en zigzag de material resinoso. Complementariamente, el Museo Etnográfico custodia una jarra de una capacidad media de 1,5 litros y un formato similar a los actuales, junto con formas más abiertas y planas (Figura 2) que corresponden a los habituales platos o escudillas de poca capacidad.

Los recipientes globulares como las jarras, la tinaja y la olla también fueron confeccionados con arcilla desgrasada con hueso calcinado molido y de manera similar a los botijos, mediante la combinación de encabalgamientos para ampliar o reducir el diámetro del recipiente. En todos los casos las bases son planas, posiblemente realizadas por una bola de arcilla aplastada, ya que no se evidencian roturas o depresiones circulares. El pico se logró mediante pellizcado del borde de la pieza y su posterior modelado, mientras que las asas, de buen tamaño, responden al tipo de cinta vertical y están pegadas al cuerpo de la pieza. Por otro lado, las formas abiertas se conforman por la superposición externa de rollos sobre una base plana. Todas estas piezas están terminadas con un simple alisado, y cocidas en atmósfera oxidante incompleta, en el caso de la olla y la tinaja, y reductora en el resto del conjunto (Tabla 2).

El repertorio formal de las piezas de principios de siglo tiene una orientación fundamentalmente funcional, para uso propio del grupo productor o su entorno inmediato. La abundancia de botijos en las colecciones -una forma que también domina las muestras de otros pueblos chaqueños de la época- seguramente implique un sesgo en la recolección, pero también debió de ser un objeto muy frecuente en el pasado: todos los informantes consultados lo recuerdan como la cerámica ancestral (de "mi viejita [abuela]") por excelencia y dan cuenta de su utilidad y características. Si bien las formas abiertas serían también un tipo de recipiente numeroso debido a su vinculación con el consumo de bebidas y comidas, responden a un formato fácil de reemplazar por materiales más livianos, como mencionamos anteriormente.

La dieta de los Qom de principios del siglo XX se basaba en un amplio rango de alimentos, pero pocos de ellos necesitaban la cerámica para su preparación y consumo, ya que era frecuente el asado y el tostado (Arenas, 2003), al igual que ocurre en la actualidad entre los pobladores de los parajes. El acarreo de agua y su conservación, por otro lado, se vería favorecido por la implementación de recipientes cerámicos duraderos, aunque no sería la única opción disponible, como lo demuestra el uso de 


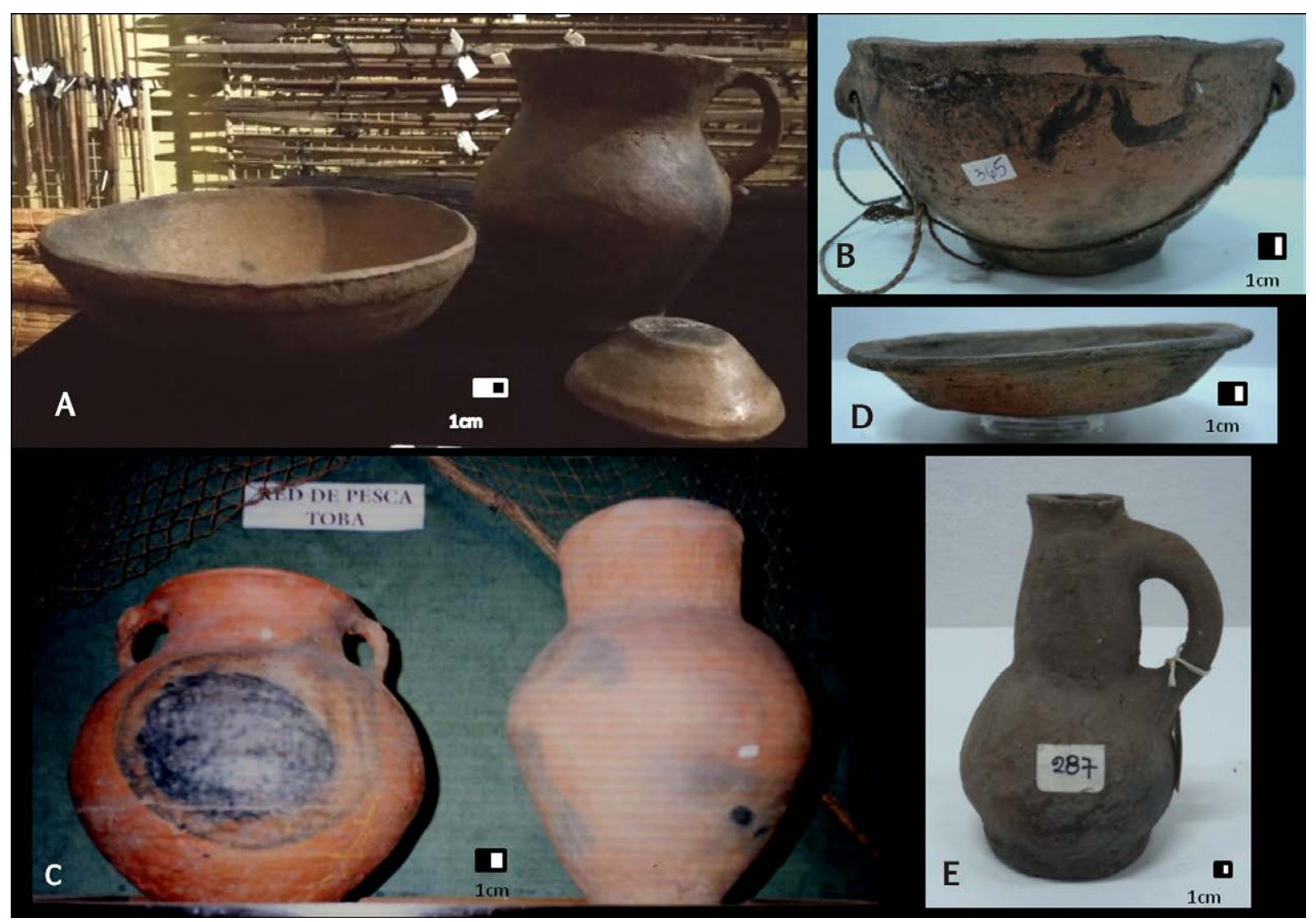

Figura 2. Otros tipos de vasijas realizadas por los qom: A) en Formosa hacia 1940 (Museo Etnográfico “]. B. Ambrosetti” (fotografía de la autora); $B, C, D$ y E) en Chaco a finales de la misma década (fotografías del Museo Histórico Regional Ichoalay).

bateas de yuchán para la fermentación tradicional de la aloja (Suárez, 2009). Por otro lado, no debemos olvidar las menciones a los botijos pequeños para la conservación de miel y grasa de pescado, que en ocasiones se enterraban para utilizarlos en épocas de escasez (Arenas, 2003). Un uso adicional es el de recipientes para fermentar las larvas que serían utilizadas en la pesca (Arenas, 2003), importante fuente de proteínas.

En cuanto a la reducida variedad morfológica identificada, cabe notar que la calidad técnica de los botijos muestra una acabada experticia en el manejo de la tecnología cerámica y la disponibilidad de materias primas para su elaboración. La restricción de materiales cerámicos muy probablemente se deba entonces a una decisión cultural que no estaría condicionada por cuestiones tecnológicas sino por otros intereses económicos (peso, fragilidad) o simbólicos (p. ej., valor intangible del yuchán como lugar mítico; Suárez, 2009).

\section{Influencias externas y cambios domésticos}

A partir de la campaña de la campaña militar al Chaco de finales del siglo XIX se intensificó el avance militar y agrícola a la vez que se establecieron haciendas privadas y misiones de distintas órdenes religiosas, mayoritariamente franciscanas y anglicanas (Giordano, 2004). Junto a ellas (y con frecuencia dependientes de la mano de obra que les facilitaban al adoctrinar a los "indios amigos" en la economía agrícola y fabril) se establecieron emprendimientos industriales como las tanineras, madereras e ingenios azucareros, que ocuparon a las familias qom y de otros pueblos chaqueños en condiciones de trabajo prácticamente esclavistas (Cordeu y Siffredi, 1971; Lagos, 
2002; Níklison, 1916), una práctica que redundó, además de la muerte de numerosos indígenas, en la pérdida de algunos valores y expresiones culturales materiales más propias de la vida nómade, como podría ser la cerámica de botijos. No hemos podido localizar ejemplares de este tipo correspondientes a cronologías de mediados del siglo XX y solo es recordada en un contexto de uso por unos pocos informantes que habitaron en parajes alejados durante su niñez. En este sentido, es excepcional el registro fotográfico de Grete Stern (Martini, 2005) en el interior del Chaco, ya que en algunas imágenes fechadas a finales de 1950 se distinguen botijos tradicionales similares a los descritos anteriormente, que posiblemente hayan seguido vigentes en contextos rurales y de monte.

Un aspecto interesante que surge al comparar las piezas de estas fotografías con el material disponible de décadas anteriores es el tipo de base utilizada. En los botijos domina la base redondeada, mientras que el resto de las piezas se asientan sobre un disco plano. Las reproducciones de botijos que realizaron los informantes sin acceso a las piezas de museo siempre describen bases planas (Figura 1). Si bien no podemos ser taxativos al respecto, puede plantearse un cambio en los hábitos de consumo y conservación de alimentos que estarían vinculados con las costumbres impartidas en las misiones (Paucke, 1943[1749-1767]) y observadas en los inmigrantes. La utilización de la mesa para comer pudo haber requerido vasijas con base plana, una posible indicación de la sedentarización y adaptación del ámbito doméstico a las nuevas costumbres.

\section{Migraciones a las ciudades}

Hacia finales de la década de 1950, los viajes estacionales a lugares de trabajo se intensifican. Asimismo, comienza una migración hacia las ciudades de la zona (Formosa, Resistencia, Juan José Castelli, Roque Sáenz Peña, Santa Fe, Rosario) y el conurbano bonaerense (Lenton et al., 1992; Wright, 2001). En general, el origen de estos asentamientos estuvo marcado por la pobreza y la exclusión social, donde las necesidades básicas de alimentación, vivienda, educación y trabajo distaban de estar satisfechas. En este contexto, y con un mayor acceso a recipientes primero metálicos y de vidrio, y luego plásticos, la cerámica utilitaria de uso culinario no sería fundamental. Sin embargo, en lugar de desaparecer totalmente, se recuperó la producción alfarera, pero con intereses diferentes.

El Barrio Toba de Resistencia es en la actualidad el núcleo urbano más grande de población indígena de la zona (Ebel y Fernández, 2015) y el primero en definirse como tal. Hacia 1958 se estableció un grupo de unos 800 pobladores - en su mayoría Qom, pero también vilela y criollos - en las afueras de la capital (Hermitte, Iñigo Carrera e Isla, 1995). Al integrar a los sucesivos grupos migratorios, el Barrio Toba se configuró entre los intentos oficiales por invisibilizar a los indígenas y los de la Cruz Roja por crear instituciones de contención e integración al mundo urbano (Quevedo, 2017). En esa pugna, la población indígena, despojada de sus tierras y de parte de su cultura material, se reinterpretó a sí misma y recuperó o, en ocasiones, creó, rasgos definitorios a partir del bagaje inmaterial que conservaba de prácticas ancestrales. Por sus características, la alfarería de la época puede leerse como el reflejo de la voluntad de los desplazados por expresar los valores de la cultura Qom en nuevos formatos aceptables a la sociedad en la que ahora se enmarcaban.

Las colecciones de cerámica qom del Museo Sotelo, del Museo de América, del Museo Nacional del Hombre y algunas piezas del Museo del Hombre Chaqueño dan cuenta de esta transición. Durante las décadas de 1960 y 1970 surge con renovada fuerza un repertorio cerámico diferente al del período anterior, pero con una fuerte marca identitaria y rasgos que perdurarán hasta la actualidad. 
Algunos autores contemporáneos que estudiaron las artesanías chaqueñas en esa época - como Oscar Cerrutti (1966), Marcos Altamirano (1968) o Clara Passafari (1975) - vieron con cierto recelo estos cambios en la práctica artesanal, que, por otro lado, no eran exclusivos de la cerámica qom, como puede leerse en la siguiente frase de Altamirano (1968):

En Villa Ángela y Napalpí aborígenes Mocovíes practican un arte que progresivamente ha evolucionado hacia formas modernas y prácticamente se está convirtiendo en una artesanía folk. En Resistencia existe una pequeña empresa artesanal [la Cooperativa Albalopi] cuya comercialización está a cargo de los mismos productores aborígenes [qom del Barrio Toba]. En otros lugares sólo unas pocas viejas indígenas mantienen la tradición artesanal alfarera y textil (Altamirano 1968, pp. 76-77).

Podemos deducir de las observaciones de Altamirano que la tradición cerámica de momentos anteriores pervivió en algunas localidades, donde seguramente seguiría siendo útil en la vida doméstica de los pobladores para el acarreo y tratamiento de agua, así como para la conservación y consumo de alimentos. También es probable que, como sucedió en los ingenios (Sánchez, 2007) y se observa en las fotografías de Stern, los recipientes de hojalata reciclados fueran reemplazando a la cerámica. Lamentablemente, los ejemplares cerámicos recogidos por los investigadores contemporáneos en el interior del Chaco corresponden a cerámica decorativa, por lo cual no podemos sacar conclusiones al respecto.

Lo que sí podemos atestiguar es el proceso de reinterpretación de la cerámica que surgió en el Barrio Toba de Resistencia y en Colonia Aborigen-Quitilipi. En el caso de Resistencia, a mediados de la década de 1960 identificamos dos producciones cerámicas distintivas. Por un lado, se creó un repertorio de miniaturas decorativas destinadas a un público externo; por otro, se incorporaron nuevos aspectos tecnológicos afines a los de la cerámica moqoit contemporánea en la manufactura y el acabado de superficie de las vasijas y, en muchas de ellas, se impuso un modelo decorativo innovador que reprodujo rasgos antropomorfos modelados.

La cerámica con formatos adaptados para la venta a los turistas (Figura 3) fue muy popular entre la década de 1960 y 1970. Sus diseños se continúan en los actuales "recuerdos étnicos" que se ofrecen tanto en Chaco como en las ferias artesanales de las provincias de Buenos Aires y Santa Fe. Estas piezas fueron popularizadas por un programa financiado por el Consejo Federal de Inversiones a finales de 1960 que perseguía fines culturales, como su exposición en el entonces Instituto Nacional de Antropología (1972), y la distribución y venta en distintos lugares del país, en particular las grandes ciudades y lugares de interés turístico (Elbert, 1973). Hacia 1970, la cerámica qom fue muy buscada por los viajeros a Resistencia: relatan algunas alfareras (JC, TP) que las piezas se vendían en la Plaza 25 de Mayo o en el antiguo puente que comunicaba con Corrientes, pero era frecuente que los turistas se acercaran hasta el Barrio Toba para adquirirlas en la Cooperativa Albalopi ("alfarero", en lengua Qom laqtaq) o incluso en la casa de los ceramistas. El repertorio incluyó diseños que no se elaboraban anteriormente (pavas) o que, de existir, se miniaturizaron (jarras, ollas) o estandarizaron (animalitos) para satisfacer los gustos y las necesidades de transporte y presupuesto de los visitantes. La producción de la época fue tan grande y el público tan poco exigente que se modificó la técnica utilizada de manera que permitiera producir un mayor número de piezas e incluso incorporar alfareros con escasa formación (TP, JC). Surgieron en este momento las máscaras realizadas en planchas de barro dobladas sobre el muslo o una teja española (JC) y pintadas con colores tierra. Las vasijas en miniatura y los animalitos se realizaron por estiramiento de una bola de arcilla desgrasada con aserrín y tenían un acabado somero. Una proporción menor era terminada con un ligero pulido, dibujos pintados en negro o asas de carandillo. Muchas piezas no se cocían, pese a lo cual han resistido inalteradas medio siglo. Otras piezas se 


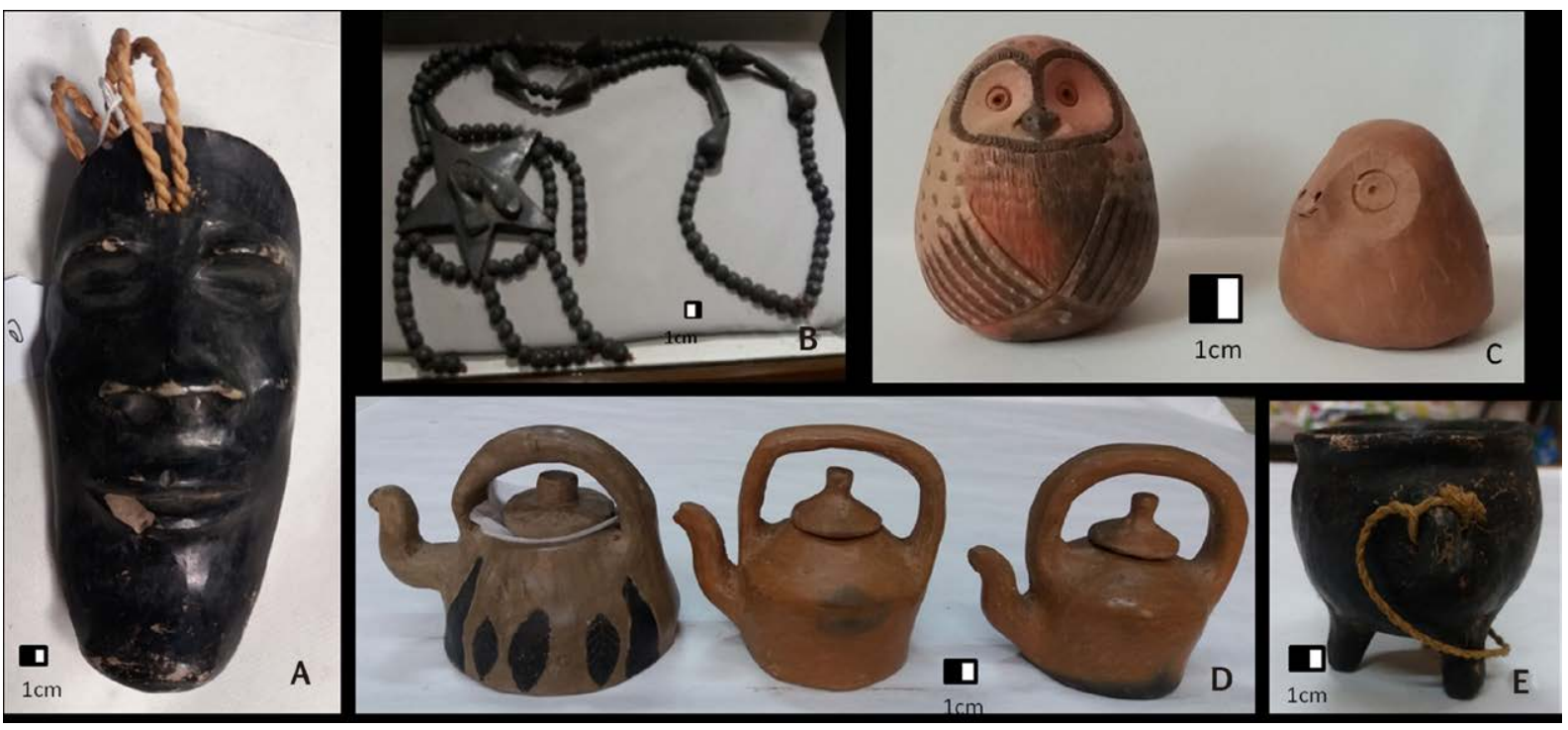

Figura 3. Cerámica elaborada para la venta a turistas en las décadas de 1960-70: A) Museo de América; B, D, E) Museo Nacional del Hombre; C) colección particular (fotografías de la autora).

sometían a atmósferas oxidantes en un horno de uso comunitario construido por la Cruz Roja (Romero, 2017) o a atmósfera reductora en los hogares. Pese a los esfuerzos de esta institución por crear asociaciones de trabajo, los alfareros continuaron trabajando de manera individual o familiar.

El segundo tipo de piezas producidas en los inicios del Barrio Toba presenta modificaciones tecnológicas que las acercan a la cerámica moqoit (Vidal, 2019). De los botijos globulares de gran diámetro se pasa a modelar piezas estilizadas tendientes a la verticalidad, los alisados desaparecen para ser reemplazados por pulidos o estar recubiertos por betún traslúcido en un intento por imitarlos, y se consolida la base plana con abundante desgrasante (Figura 4). No hemos podido precisar el origen de esta influencia. En el informe de Elbert (1973) se menciona la presencia de talleres y docentes para adaptar la producción cerámica a los cánones urbanos. Sin embargo, ninguno de los descendientes de los alfareros de las décadas de 1960-1970 (JC, TP, VS) ni otros habitantes del Barrio Toba recuerda dicha formación, ni las voluntarias de la Cruz Roja dan cuenta de la misma, y solo rescatan la construcción del horno y el local de uso común. Complementariamente, el reconocido alfarero qom Raúl Sotelo (JC) enseñaba cerámica en la escuela primaria del Barrio, pero se limitaba a figuras muy simples. Asimismo, la documentación de Vellard (Colazo, 2012), que incluye estudios antropométricos a los habitantes del Barrio, registra personas de ancestría qom y vilela, pero no moqoit.

Por otro lado, una situación similar se produjo en Quitilipi y Colonia Aborigen, pero esta vez la familia Sotelo-Aguirre conserva la documentación del proceso. En la zona (distante $138 \mathrm{~km}$ de Resistencia), la cerámica qom de mediados del siglo XX era prácticamente inexistente y de baja calidad, hasta que a mediados de la década de 1960 René Sotelo organizó viajes a Villa Ángela (Chaco) para que los alfareros qom tuvieran la posibilidad de perfeccionar o recuperar esta tecnología. El programa cumplió su objetivo y en la actualidad esta influencia es muy marcada en la zona, al punto de ser sumamente difícil distinguir las piezas qom de las moqoit, con excepción de la finura de las paredes y el uso de aserrín en el caso de los primeros. Experiencias similares pudieron haber ocurrido en el Barrio Toba de Resistencia pero, por el momento, no hemos localizado a los involucrados. Cabe señalar que en la actualidad quienes modelan vasijas en el Barrio han vuelto a los modelos y acabados previos a la década de 1960. 


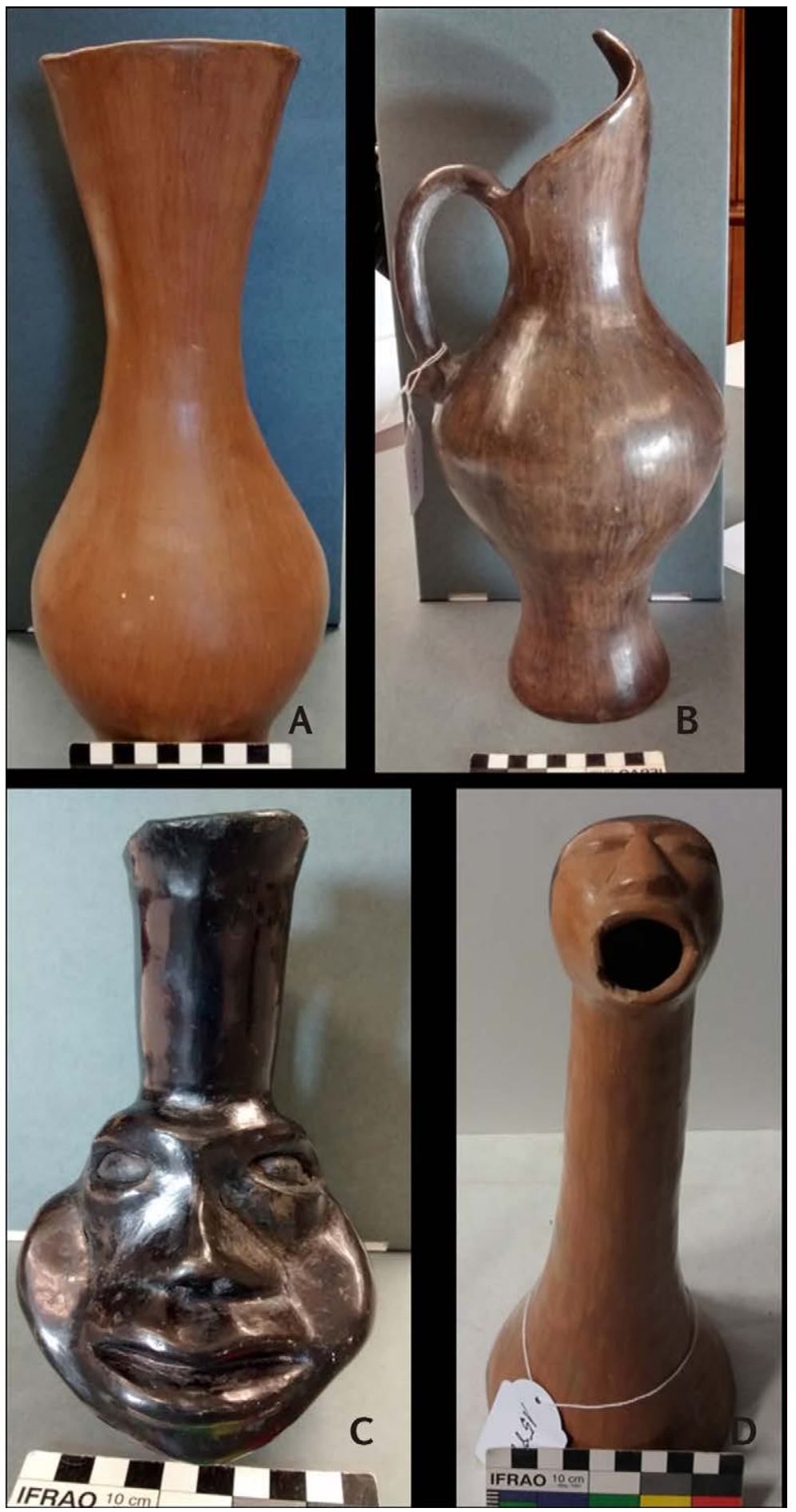

Figura 4. $A$ y B) Contenedores de cerámica con influencia moqoit; $C$ y $D$ ) vasijas de influencia moqoit con rostro modelado (Museo de América) (fotografías de la autora).

En la mayoría de estas vasijas se continuó utilizando el desgrasante de hueso, con una proporción que varía entre el 30\% y el 60\% según la parte considerada, ya que su mitad inferior concentra una mayor cantidad de inclusiones. La diferencia parece responder al proceso de modelado que utilizan actualmente las alfareras moqoit, en el cual la vasija se coloca sobre una superficie espolvoreada con abundante ceniza de hueso que se va incorporando a la base a medida que se gira para levantar las 
1. Informantes de ancestría qom, wichí, moqoit, criolla y europea en Resistencia, qom y europea en Colonia Aborigen y Quitilipi, qom, wichí, criolla y europea en Miraflores y moqoit en San Bernardo. paredes. Por otro lado, poco más de un tercio de la muestra disponible presenta desgrasante de aserrín, con pastas similares a las de las piezas que hemos definido como recuerdos turísticos. Esta composición es la preferida actualmente por los alfareros qom, independientemente de su localización. Según relatan JC y TP, el aserrín, utilizado ya por sus padres y abuelos desde su llegada al Barrio (hacia 1960), es más fácil de conseguir y permite modelar piezas más livianas que secan más rápidamente y se cuecen de manera más uniforme.

En cuanto a la técnica, es preciso señalar que todas las piezas se modelaron a partir de una base circular plana y fueron levantadas por superposición en espiral, con encabalgamiento externo en las partes salientes e interno en las entrantes. Tanto la unión de los rollos como el acabado de las paredes fueron meticulosamente tratados, con obliteración de marcas y homogeneización del grosor en toda la vasija. La cocción fue en general muy pareja y las paredes alternan entre ejemplares finos (unos $7 \mathrm{~mm}$ en las piezas con desgrasante de aserrín) y otros más gruesos al incorporar el hueso molido (Vidal, en prensa).

$\mathrm{Al}$ considerar las morfologías, distinguimos dos subtipos. El primero engloba todas las piezas con formas y dimensiones similares a la cerámica moqoit contemporánea (Figura 4A-B): piezas de gran tamaño, muy bruñidas, formadas por tipos bien definidos (jarras, jarrones) o superposición y combinación de elementos básicos como cuerpos globulares, apéndices tubulares, brazos que terminan en bocas o representaciones esquemáticas zoo y fitomorfas. El segundo grupo está comprendido por piezas de formatos o bien globulares o bien por una combinación de un cuerpo globular con un cuello cónico invertido o tubular, donde se aprovechó la zona abombada para modelar un rostro humano, con escasas excepciones (Figura 4C-D). Si bien existen diferencias según la creatividad del artista, todos presentan ojos almendrados, cejas marcadas, nariz $\mathrm{y}$ frente anchas, labios gruesos, carrillos abultados y, con frecuencia, una protuberancia señalando la barbilla. Estos rasgos definirían la fisonomía característica de los Qom, según nos relatan los informantes consultados de esta etnia y de otros pueblos chaqueños ${ }^{1}$ (Vidal, en prensa). Estos mismos rasgos se modelaban en las máscaras, posiblemente definiendo un modelo de lo que se consideraba un rostro típicamente Qom. La incorporación de rasgos faciales es sin duda singular, ya que se trata de una decoración que no se encuentra en otras cerámicas del grupo guaycurú (Vidal, 2018b) y solo unas pocas parcialidades wichí y chorote la utilizan en sus botijos y botellas de la primera mitad del siglo XX en el Chaco salteño (Vidal, 2018b).

Un proceso diferente siguen las estatuillas humanas modeladas por la familia Chara: se trata de verdaderas esculturas en arcilla que siguen una tradición familiar iniciada a finales de la década 1960 por quien fuera el maestro de cerámica en la escuela del Barrio Toba (Vidal, en prensa). Estas figuras representan a jóvenes y familias Qom realizando actividades domésticas típicas de la vida en el monte, sin caer en estereotipos y respetando posturas, gestos y vestimentas clásicas de los Qom precoloniales.

La vida en la ciudad representó para los Qom la pérdida de algunas prácticas y costumbres, como la relación directa con los medios de subsistencia, en la que participaba el repertorio cerámico elaborado hasta mediados de siglo. Por otro lado, incorporó nuevas herramientas, materiales y costumbres que fueron desplazando la necesidad de producir vasijas funcionales. La nueva relación con la cerámica se estableció en términos de medios económicos, donde su uso directo dejó de ser válido para transformarse en un producto de intercambio que a través de la venta permitía satisfacer antiguas y nuevas necesidades. El nuevo modelo de producción cerámica constituyó así una fuente de ingreso y se buscaron formas de incentivarlo. Entró entonces en juego la negociación de los términos en que se realizaba la cerámica: se cambió la tecnología para simplificar el proceso y cubrir los intereses del nuevo público 
receptor, pero en algunos casos - como los rostros - se incorporaron elementos que facilitaban su identificación étnica sin desconocer la creatividad individual.

Basándonos en la intencional caracterización de estas formas, podríamos interpretar estas piezas como un acto de resistencia y reafirmación de la identidad indígena en un contexto en el que los Qom - que migraron pocos años antes al Barrio Toba- se estaban acomodando a la vida en la periferia de una ciudad que les resultaba hostil y con formas de vida, recursos y valores opuestos al monte originario. La representación en la cerámica funcionaría así como una reivindicación de los valores culturales latentes en los nuevos migrantes que encontraron en un formato nuevo la manera de expresar su tradición ancestral y reconocerse a sí mismos. Quizás por ello esta expresión material tan característica se perdió a las dos décadas de nacida, cuando las exigencias de la vida en la ciudad cambiaron, la participación en la rutina citadina fue más frecuente — si bien en condiciones desiguales - y parte de la población migró a otros barrios (Mapic, Cacique Pelayo, distintas zonas de Resistencia) o núcleos urbanos cercanos (como Colonia Aborigen) y no fue prioritario - o deseado, o posible- demarcar los orígenes étnicos de manera tan clara.

\section{Dictadura, pérdida de territorio e industrialización}

Al igual que en el resto del país, la dictadura militar provocó un cambio considerable en la vida chaqueña. La atención que actualmente se presta a la historia de las persecuciones y muertes de poblaciones originarias (Chico, 2014) deja en evidencia la participación no solo de autoridades militares sino también de civiles con gran influencia política y económica. En el caso del área chaqueña, este período estuvo acompañado además de la acelerada expansión de la propiedad privada a expensas de las tierras comunales y la creciente industrialización y pauperización de la clase obrera que incluía a los pueblos originarios.

Durante la década de 1980, con el final de dictadura y la restauración democrática, la población indígena de zonas urbanas y rurales comenzó a reorganizarse, con la consecuente movilización de contingentes entre distintas zonas. También en este momento asesinan a René James Sotelo (Sotelo, 2018), con lo cual los artesanos chaqueños pierden a su más acérrimo defensor y los estudios americanistas locales a uno de sus pioneros. Años después, sus descendientes, con variado apoyo oficial y una amplia participación comunitaria, siguen celebrando anualmente la Feria de Artesanías Aborígenes en Quitilipi (Chaco).

Como ocurrió con la década de 1950, la de 1980 no tiene casi representantes en el repertorio cerámico de los museos. En Quitilipi se conservan algunas piezas de las ferias de esos años que mantienen las características previas: dominio del material desgrasado con aserrín, paredes pulidas, formas aptas para un uso urbano, miniaturas y animalitos. En cuanto a los parajes del interior, no hemos recogido referencias al uso de la cerámica. Un dato que apareció con frecuencia en los relatos fue la mayor disponibilidad de recipientes plásticos y el ingreso de donaciones que incluían menaje importado, que pudieron haber desplazado la alfarería indígena.

\section{Cambio de milenio}

La situación actual de la cerámica qom se remonta en cuanto a tecnología y diseños a finales de la década de 1990. Una parte importante de la producción se localiza en un ambiente urbano, o en la periferia de las ciudades, contextos sumamente influenciados por la lógica mercantilista y donde vive actualmente la mayor parte de la población de esta etnia. La otra parte se encuentra en los centros donde la cerámica había florecido décadas antes: los barrios indígenas de Resistencia y la zona de Colonia Aborigen. 
En el interior provincial prácticamente no hay alfareros, si bien en algunos sitios, como Pampa del Indio, se está recuperando la artesanía, con modelos que imitan la producción de los centros antes mencionados.

En Colonia Aborigen-Quitilipi (SO, PG, familia José) y en Resistencia-Fontana (JC, VS) se mantiene la alfarería de vasijas, a la que se suma un conjunto de piezas huecas de gran calidad y diseños innovadores en el primer caso (Figura 5), y las clásicas estatuillas humanas de la familia Chara en el segundo. La formación de algunos alfareros en Quitilipi se evidencia en puntos distantes como Miraflores (EM) o Pampa del Indio (López y López, 2011), pero su producción es ocasional. En todas estas localidades las vasijas se siguen realizando por superposición de rollos en espiral sobre una base plana, alternando encabalgamientos según se intente aumentar o reducir la circunferencia de la pieza. Donde todavía es posible extraer arcillas de calidad (Fontana -JC y VS-, Colonia Aborigen -SO y PG-, Pampa del Indio), los artesanos utilizan aserrín como desgrasante en altas proporciones (casi 50\%), que resulta en piezas más ligeras y cocción más rápida y uniforme. En el caso de los modelos más tradicionales, se incorporan asas y cuerdas de fibra vegetal, mientras que en los más creativos, se agregan o modifican formas base para conseguir nuevos formatos, muchos de ellos exclusivamente decorativos. Estas piezas tienen paredes particularmente finas y, en las localidades del interior, las superficies están pulidas y con frecuencia presentan alguna decoración como impresión, incisión o incluso pintura. En el caso de Roque Sáenz Peña, en los últimos años se han comenzado a modelar rostros humanos estilizados, con collares y adornos plumarios que difieren de los modelos anteriores. Para la cocción se utiliza leña y, si bien se suele preferir la hoguera a cielo abierto, ocasionalmente se quema en los hornos de pan cuando la producción es grande.

En las zonas urbanas, los alfareros qom (Figura 6) buscaron el modelo a seguir en los diseños que le resultaron más cercanos en tiempo y espacio. Se reproducen mayoritariamente los formatos que surgieron en la década de 1960 destinados a un público externo a la comunidad (López y López, 2011; Vidal, 2017): tanto en las provincias de Buenos Aires y Santa Fe como en las chaqueñas, proliferan las imágenes de lechuzas, palomas/charatas y manitos, junto con máscaras y collares, adaptándose a las exigencias del mercado ferial de artesanías y los comercios de recuerdos de viaje. Son cerámicas realizadas por estiramiento de una bola de arcilla y modeladas a mano -con un repertorio muy reducido de personajes- en el caso de las figuras, o modeladas sobre una placa de arcilla, en el de las máscaras. En estas localidades, la mayor dificultad para conseguir la materia prima y su elevado costo justifica la elección de arcilla industrializada que es fácil de manipular y tiene menor riesgo de roturas al ser cocida en horno. Las decoraciones con profusión de colores de origen artificial se realzan con un acabado brilloso que no se obtiene por pulido sino mediante la aplicación de un barniz o pomada para cueros, con un efecto similar pero una menor inversión de trabajo. Seguramente por su abundancia y contemporaneidad, estas piezas son las que popularmente se conocen como "cerámica qom" y que definen popularmente a este pueblo, en particular, en las zonas ajenas a sus territorios de origen.

Pese a su introducción como actividad económica de mercado —o quizás debido a ello-, la cerámica sigue formando parte del repertorio cultural Qom y en ocasiones da origen a justificaciones y mitos reinterpretados donde se conjugan las antiguas tradiciones con la forma de vida actual (López y López, 2011). Su uso vinculado al ámbito doméstico, empero, es desdeñado y el modelado de formas utilitarias se interpreta exclusivamente en términos decorativos. Con esta explicación se justifica la presencia de pequeños agujeros en los galbos y el notable aumento de la porosidad por la abundancia de aserrín, factores que atentan contra la posibilidad de utilizar las piezas como contenedor de líquidos. 


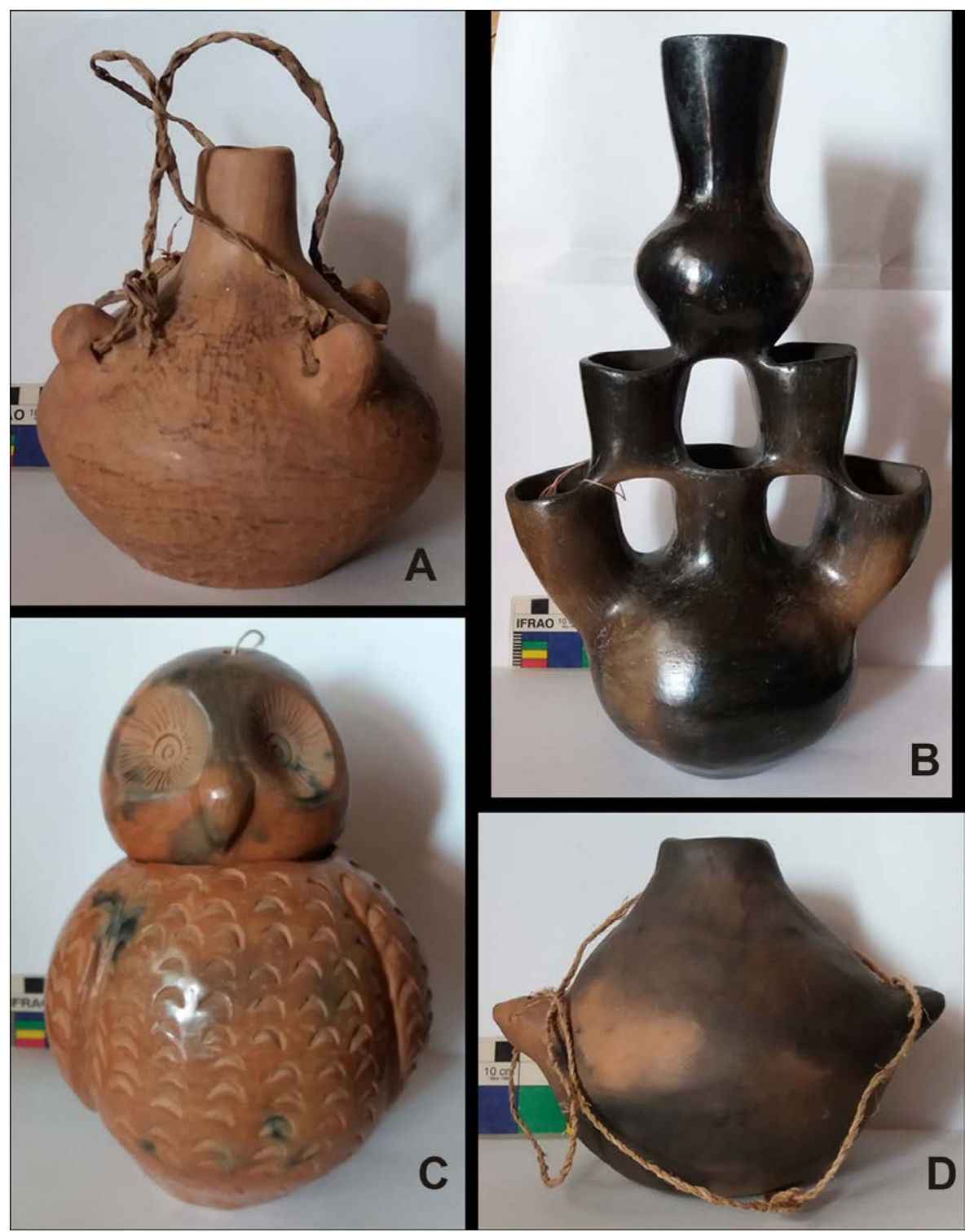

Figura 5. Modelos qom actuales: $A$ y $D$ ) recipientes tradicionales; $B$ y $C$ ) vasijas innovadoras (colección particular) (fotografías de la autora).
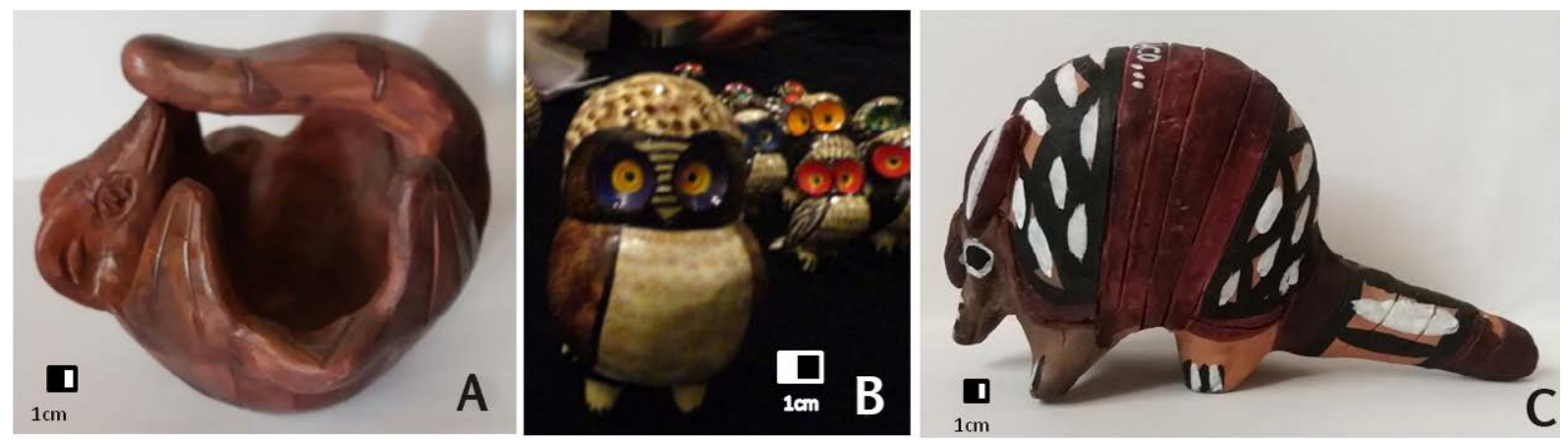

Figura 6. Cerámica qom ofrecida en ferias de artesanía, eventos culturales y puntos de interés turístico en las provincias de Buenos Aires, Chaco y Santa Fe: A) tatú-cenicero (Rosario, Santa Fe); B) lechuzas (Derqui, Buenos Aires); C) tatú (Villa Ángela, Chaco) (colección particular) (fotografías de la autora). 


\section{Conclusiones}

Mediante el estudio de las colecciones de cerámica qom disponibles y los relatos de alfareros de esta etnia hemos intentado trazar el desarrollo diacrónico de esta tecnología no solo en términos materiales sino también en el papel que jugaron en la sociedad productora. Partimos del concepto de los botijos y otras piezas de menaje como herramientas útiles para recoger, depurar y conservar agua y alimentos en la vida montaraz de principios de siglo. En aquellos parajes donde la relación con estos recursos no fue mediada por la economía de mercado, esta tradición podría haber perdurado hasta hace tres generaciones. A partir de entonces, los informantes no recuerdan el uso culinario de cerámicas, que se sustituye por materiales industriales. Pasada la mitad del siglo XX en los núcleos urbanos cercanos a Resistencia donde se asentó parte de la población Qom desplazada se desarrolló una alfarería variada que tuvo como público los turistas interesados en "recuerdos étnicos". Sin embargo, no se trató de producciones totalmente ajenas a la identidad Qom: se tomaron nuevas referencias como la fisonomía o los adornos asociados a esta etnia para algunas representaciones. Tras un período de declive, hacia finales del siglo los núcleos alfareros qom más tradicionales continuaron trabajando con las técnicas antiguas y algunos modelos de mitad de siglo, pero introdujeron cambios en la composición que facilita su elaboración, desvinculando esta variable de la funcionalidad originaria de la pieza. Por otro lado, en la periferia de las ciudades se intentó generar un producto que sea bien recibido por el público externo a la comunidad pero sin renunciar a las tradiciones y mitos, que se reflejan en la elección de los elementos representados. A día de hoy, los Qom residentes en distintas localidades reivindican como propias las distintas tipologías que hemos identificado, reconociendo un vínculo histórico de larga data. De esta manera, la cerámica continúa siendo una manifestación sociocultural identitaria pese a su alto sentido económico y funciona como uno de los múltiples mecanismos que los Qom han desarrollado para mantenerse vinculados a sus orígenes.

\section{Agradecimientos}

Mi gratitud por sus enseñanzas y cariño a los alfareros qom de la provincia de Chaco: Ema Méndez, Jessica Chara, Teresa Pichón, Vicencio Segundo, Sara Ortega y Patricia Gómez. Asimismo, agradezco a Ana Romero y Lino Prado por llevarme a Colonia Aborigen, a la familia Sotelo-Aguirre por abrirme su casa y sus archivos, a Ingrid Muller por las grabaciones de Vicencio Segundo, a Belkis Castaño por los datos sobre Barrio Toba y las donaciones al MAM y al Museo Ichoalay. También quisiera agradecer a los responsables de los Museos Nacional del Hombre-INAPL, "R. J. Sotelo", "Ichoalay", del Hombre Chaqueño, de América de Madrid, de Charata y Etnográfico "J. B. Ambrosetti” por su tiempo y el acceso a los fondos y la información. Este trabajo se enmarca en una beca del Fondo Regional de las Artes/Partido de Tres de Febrero de 2018 y otra del Programa Investiga Cultura 2017-18. Finalmente, agradezco a los evaluadores anónimos por sus aportes para mejorar el manuscrito de este trabajo. 


\section{Q Referencias bibliográficas}

" Altamirano, M. (1968). Los aborígenes chaqueños. Resumen etnohistórico. En G. Miranda, S. Geraldi, C. Lopez Piacentini, R. Sotelo, J. Miranda Borelli, M. Altamirano y J. Vazques Gualtieri (Comps.), Aportes para la Historia del Chaco (pp. 53-82). Resistencia: Biblioteca "El Territorio", Lotería Chaqueña.

》Alvarsson, J. (2012). Belleza y Utilidad. La Cultura Material. Villa Montes: Serie Etnografía 'Weenhayek 3, Universidad de Uppsala-FI'WEN.

» Arenas, P. (2003). Etnografía y Alimentación entre los Toba-ñachilamoleeky Wichí-Ihuku’tas del Chaco Central (Argentina). Buenos Aires: Edición del autor.

» Braunstein, J. (1983). Algunos Rasgos de la Organización Social de los Indígenas del Gran Chaco. Buenos Aires: EUDEBA.

"Calandra, H., Balbarrey, G., Couso, G., Lamenza, G., Aguirre, B. y Duhalde, N. (2004). El sitio "Las Bolivianas" (Formosa): Análisis comparativo del material cerámico del Sector Central del Gran Chaco Argentino. En Actas del XXIV Encuentro de Geohistoria Regional (pp. 44-54). Resistencia: Instituto de Investigaciones Geohistoricas (IIGHI), CONICET.

"Cerrutti, O. (1966). Manual de Artesanías Indígenas. Santa Fe: Ediciones Colmegna.

"Chico, J. (2014). Los Qom de Chaco en la Guerra de Malvinas. Resistencia: Kram ediciones.

"Chico, J. (2017). Las Voces de Napalpí. Resistencia: Contexto.

"Colazo, S. (2012). La contribución de Jehan A. Vellard a los estudios de antropología en el Chaco. Universidad Austral Biblioteca. Archivo fotográfico Jean Vellard. Manuscrito inédito.

»Cordeu, E. y Siffredi, A. (1971). De la Algarroba al Algodón. Movimientos Mileniaristas del Chaco argentino. Buenos Aires: Juárez editor.

》Ebel, G. y Fernández, M. (2015). Proyecto urbano: intervención integral Gran Toba. ADNea. Revista de Arquitectura y Diseño del Nordeste Argentino, 3 (3), 29-40.

"Elbert, E. (1973). Estudio sobre el Mercado de Artesanías Regionales Argentinas. Informe preparado para el Consejo Federal de Inversiones y el Centro Experimental de Promoción Artesanal de la Universidad Nacional del Nordeste. Manuscrito inédito.

" Giordano, M. (2004). Itinerario de imágenes del indígena chaqueño. Del “Territorio Indio del Norte" al Territorio Nacional y Provincia del Chaco. Anuario de Estudios Americanos, 61(2), 517-550.

"Giordano, M. (2012). Fotografía, testimonio oral y memoria. (Re)presentaciones de indígenas e inmigrantes del Chaco (Argentina). Memoria Americana, 20(2), 295-320.

» Hermitte, E., Iñigo Carrera, N. e Isla, A. (1995). Estudio sobre la Situación de los Aborígenes en la Provincia del Chaco y Políticas para su Integración a la Sociedad Nacional. Posadas: Editorial Universitaria de Misiones.

"Instituto Nacional de Antropología (1972). Catálogo de la Muestra "Culturas Indígenas del Área Chaqueña". Buenos Aires: Instituto Nacional de Antropología.

"Lagos, M. (2002). La problemática del aborigen chaqueño. El discurso de la "integración" 1870-1920. En A. Teruel y O. Jerez, O. (Eds.), Fronteras, Ciudades y Estados (pp. 65-78). Córdoba: Acción. 
»Lamenza, G. (2015). Utilización del análisis multivariante para la sistematización del componente alfarero del Chaco prehispánico. Arqueología Iberoamericana, 28, 52-61.

» Lamenza, G., Aguirre, B. y Calandra, H. (2005). Alfarería arqueológica del sector Paraná y Paraguay del Chaco meridional: su sistematización e identidad. En Actas del XXV Encuentro de Geohistoria Regional [CD ROM]. Corrientes: Instituto de Investigaciones Geohistoricas (IIGHI), CONICET.

» Lenton, D., Slavsky, L., Bigot, M., Rodríguez, G., Vázquez, H., Tamagno, L., Fraguas, M. y Radovich, J. (1992). Problemática Indígena: Estudios Antropológicos sobre Pueblos Indígenas de la Argentina. Buenos Aires: Centro Editor de América Latina.

» López, C. y López, S. (2011). Daviaxaiqui. Buenos Aires: Ediciones Nahuatonaxanaxac.

" Martini, J. (Ed.) (2005). Aborígenes del Gran Chaco. Fotografías de Grete Stern 1958-1964. Buenos Aires: Fundación Antorchas - Fundación CEPPA (Centro de Estudios para Políticas Públicas Aplicadas).

" Métraux, A. (1946). Ethnography of the Chaco. En J. Steward (Ed.), Handbook of South American Indians 1 (pp. 197-370). Washington D.C.: Smithsonian Institution, Bureau of American Ethnology.

» Níklison, J. (1916). Investigación en los territorios federales del Chaco y Formosa. Boletín del Departamento Nacional del Trabajo, 38(2), libros III y IV. Buenos Aires: Imprenta y Encuadernación de la Policía.

» Nordenskiöld, E. (1920). The Changes in the Material Culture of Two Indian Tribes under the Influence of New Surroundings. Comparative Ethnographical Studies 2. Gotemburgo: Elanders Boktryckeri AB.

»Palavecino, E. (1944). Alfarería chaqueña. Relaciones de la Sociedad Argentina de Antropología, 4, 231-235.

» Passafari, C. (1975). Artesanía y Cultura Nacional. Santa Fe: Instituto Argentino de Cultura Hispánica de Rosario.

»Paucke, F. (1943[1749-1767]). Hacia Allá y para Acá (una Estadía entre los Indios Mocobíes, 1749-1767). Tomo II. San Miguel de Tucumán: Instituto de Antropología.

»Pegoraro, A. y Elías, M. (2010). Documentación de colecciones etnográficas: los desafíos de los tiempos actuales. El caso de las colecciones etnográficas del Museo Etnográfico “Juan B. Ambrosetti” de la Universidad de Buenos Aires. Manuscrito inédito.

»Quevedo, C. (2017). Imaginario integracionista, espacio doméstico y alteridad indígena en la ciudad de Resistencia. Trabajo presentado en las XXI Jornadas Nacionales de Investigadores en Comunicación ( 5 a 7 de octubre de 2017). Departamento de Ciencias de la Comunicación, Facultad de Ciencias Sociales, Universidad Nacional de San Juan. San Juan, Argentina.

» Rice, P. (1986). Pottery Analysis. A Sourcebook. Chicago: The Univerity of Chicago Press.

» Romero, V. (2017). La Madrina de los Tobas: Inés Manuela García de Marqués. Resistencia: Contexto.

"Sánchez, O. (2007). Historias de los Aborígenes Tobas del Gran Chaco Contadas por sus Ancianos. Resistencia: Acción Apostólica Común, Instituto Universitario ISEDET (Instituto Superior Evangélico de Estudios Teológicos) y Sociedad Bíblica Argentina.

»Segundo, V. (2016). Historias de las Vasijas. Testimonio Oral de Vicencio Segundo. Fontana: Colección Historias y relatos de los abuelos tobas. Ministerio de Educación, Cultura, Ciencia y Tecnología, Gobierno del Chaco.

»Sotelo, M. (2018). Maestro de Maestros. Resistencia: Documental. 
»Suárez, M. (2009) El análisis de narrativas en etnobotánica: el “yuchán” (Ceiba chodatii, Bombacaceae) en el discurso de los wichís del Chaco Semiárido salteño, Argentina. Boletín de la Sociedad Argentina de Botánica, 44(3-4), 405-419.

»Susnik, B. (1998). Artesanía Indígena. Asunción: El Lector.

» Tola, F. (2012). Yo No Estoy Solo en mi Cuerpo. Buenos Aires: Biblos.

»Trinchero, H. (2000). Los Dominios del Demonio. Civilización y Barbarie en las Fronteras de la Nación. El Chaco Central. Buenos Aires: EUDEBA.

» Vellard, J. (1933). Une mission scientifique au Paraguay. Journal de la Société des Americanistes de Paris, 25(2), 217-330.

» Vidal, A. (2017). Territorios ancestrales y alfarería ausente. La cerámica del pueblo qom (Gran Chaco, Argentina). Complutum. Número monográfico. Etnoarqueología, 28(2), 359377 .

»Vidal, A. (2018a). Agua que has de beber... Estrategias de los pueblos originarios del Gran Chaco argentino en el tratamiento de aguas. En M. Alcántara, M. García Montero y F. Sánchez López (Eds.), Memoria del $56^{\circ}$ Congreso Internacional de Americanistas (pp. 518-530), Salamanca: EUSAL.

»Vidal, A. (2018b). Patrimonio, identidad y agencia en las cerámicas etnográficas argentinas del Instituto Nacional de Antropología y Pensamiento Latinoamericano (INAPL). Informe para el Ministerio de Cultura de la Nación. Programa Investiga Cultura, 16 septiembre 2018. Manuscrito inédito.

»Vidal, A. (2019). Noxoná moqoit: alfarería etnohistórica y actual del pueblo moqoit. Programa “Investiga Cultura”. Ministerio de Cultura de la Nación Argentina. Manuscrito inédito.

»Vidal, A. (en prensa). Modelando identidades: la cerámica qom en Resistencia (Chaco, Argentina) a finales de la década de 1960. Anales del Museo de América 27.

»Wright, P. (1998). El Desierto del Chaco. Geografías de la alteridad y el estado. En A. Teruel y O. Jerez (Eds.), Pasado y Presente de un Mundo Postergado (pp. 35-56). San Salvador de Jujuy: Unidad de Investigación en Historia Regional (UnHiR), Facultad de Humanidades y Ciencias Sociales, Universidad Nacional de Jujuy.

»Wright, P. (2001). El Chaco en Buenos Aires. Entre la identidad y el desplazamiento. Relaciones de la Sociedad Argentina de Antropología, 26, 97-106.

»Wright, P. (2005). Los indígenas del Chaco argentino. En J. Martini (Ed.), Aborígenes del Gran Chaco. Fotografías de Grete Stern 1958-1964 (pp. 25-33). Buenos Aires: Fundación Antorchas - Fundación CEPPA (Centro de Estudios para Políticas Públicas Aplicadas). 